\title{
ILLUSTRATIONS
}

I. Michelle Yeoh (from Malaysia) 3

2. Chang Chen (from Taiwan) 3

3. Zhang Ziyi (from China) 3

4. Chow Yun-fat (from Hong Kong) 3

5. Taiwan poster for Pushing Hands 50

6. American poster of Eat Drink Man Woman 55

7. Hung Liu, Olympia 68

8. Hung Liu, Father's Day 73

9. Hung Liu, Grandma 74

Io. Hung Liu, Avant-Garde 75

I I. Hung Liu, Resident Alien 78

I2. Original photograph depicting execution in old Shanghai, September 190480

I3. Hung Liu, Souvenir 8I

I4. A dalumei image in Taiwan media Ioo

I5. Interview of Qian Li from part 4 of Her Fatal Ways II2 
I6. Collage of images from Searching for the Strange on the Mainland I3I

17. The set for Rivers and Mountains, Ten Thousand Li of Love 134

I8. Susan atop a building in Fruit Chan's Made in Hong Kong 145

19. Moon in the shooting scene atop Victoria Peak in Made in Hong Kong 149

20. The bank robbery in The Longest Summer 152

2I. Cameras positioned at the children's eye level in small back alleyways of working-class Hong Kong in Little Cheung ${ }_{15} 6$

22. Hou Chun-ming's woodcut print of a Lo Ting from the 1997 exhibition 160

23. René Magritte's The Collective Invention I6I

24. Life-size model of a Lo Ting ${ }_{162}$

25. An example of the Fake Art of Comics ${ }_{163}$

26. Wu Mali, Sweeties of the Century 182

\section{COLOR PLATES}

(following page II4)

I. Hung Liu, Olympia II

2. Hung Liu, Swan Song

3. Publicity photo of Her Fatal Ways depicting ideologically coded characters

4. Detail of cover of The Practice of Chineseness by Yuk-yuen Lan

5. Display in Shanghai Tang store

6. Wu Mali, Epitaph

7. Wu Mali, Stories of Women from Hsin-chuang

8. Detail of words woven into cloth from Stories of Women from Hsin-chuang

9. Wu Mali, Formosa Club (1998), interior space; wooden board, pink sponge, neon light

Io. Wu Mali, The Library

II. Detail from The Library

I2. Wu Mali, Sweeties of the Century 